\title{
A vállalkozói ökoszisztémák térbeli megjelenésének modellezési lehetőségei - tények és problémák
}

Kutatásunk célja a magyar gazdaság vállalkozói ökoszisztémáinak vizsgálata. A vállalkozói ökoszisztéma fogalma a gazdasági közösségek kialakulásának egy új megközelítésével született meg, amely a vállalkozói aktivitás minőségére helyezi a hangsúlyt, továbbá feltételezi, hogy a gazdasági közösségek célja a produktív vállalkozás megvalósítása. Településszintü adatokat felhasználva, a vállalkozás minőségének méréséhez a növekedési lehetőségek közelítő változójaként használt fundamentális $Q$ mutató empirikus reprezentációját, valamint az egységnyi tőkére jutó beruházás mutatóját alkalmaztuk. Ez utóbbi mutató településszintü aggregátuma megfelelő indikátornak bizonyult. Kutatásunk másik kérdése, hogy térben koncentrálódnak-e a településszinten vizsgált vállalkozói ökoszisztémák. Térökonometriai módszerek alkalmazásával megmutattuk, hogy nem koncentrálódnak térben azok a települések, amelyekben a vállalkozás minősége magas. Végül arra a kérdésre igyekeztünk választ adni, hogy miért jut empirikus vizsgálatunk az elméleti szakirodalomnak ellentmondó álláspontra a regionális szintü ökoszisztémákkal kapcsolatban.* Journal of Economic Literature (JEL) kód: G31, C21, L26.

Tanulmányunkban a gazdasági közösségek kialakulását új megközelítésben mutatjuk be: a vállalkozói ökoszisztémát elemezve vizsgáljuk meg, hogy a magyar gazdaságban megfigyelhetö-e empirikusan tesztelhető adatok alapján a gazdasági szereplők koncentrációja. A szakirodalomban egyre többször jelenik meg az a nézet, hogy a gazdasági növekedést nem az új vagy a kis- és középvállalatok, startup vállalkozások teszik lehetővé, hanem a vállalatoknak, vállalkozóknak egy kisebb csoportja játszik fontos szerepet e téren (Wong [2005], Anyadike-Danes és szerzőtársai [2009], Stam és szerzötársai [2009], Stam és szerzőtársai [2011], Mason-Brown [2013]). Ez a megközelítés - a mennyiségi szemléletmódon

* Szeretnénk köszönetet mondani Rappai Gábor értékes tanácsaiért, valamint köszönet illeti a Pallas Athéné Domus Scientiae Alapítványt anyagi támogatásáért.

Tóth-Pajor Ákos egyetemi tanársegéd, Pécsi Tudományegyetem Közgazdaságtudományi Kar (e-mail: toth-pajora@ktk.pte.hu).

Farkas Richárd PhD-hallgató, Pécsi Tudományegyetem Közgazdaságtudományi Kar (e-mail: farkasr@ ktk.pte.hu).

A kézirat első változata 2016. augusztus 18-án érkezett szerkesztőségünkbe.

DOI: http://dx.doi.org/10.18414/KSZ.2017.2.123 
alapuló vállalkozói aktivitás fontosságához képest - a gazdaság növekedését a vállalatok és a vállalkozók minőségétől teszi függővé (Stam [2015]). ${ }^{1}$ A vállalkozói ökoszisztéma megközelítése szerint nagy növekedési lehetőségű vállalatok és ambiciózus vállalkozók azok, akik képesek produktivitásukkal megalapozni a növekedést, elösegíteni az innovációt, támogatni a nemzetköziesedést, továbbá akiknek nagy szerepük van az új munkahelyek megteremtésében is (Stam és szerzötársai [2012], Brown-Lee [2014]). Ezenfelül a jó teljesítménynek köszönhetö közvetlen hatásokon túl más tovagyürüző impulzusokon keresztül pozitívan befolyásolhatják a lokális gazdaság növekedését is (Mason [2009], Du és szerzőtársai [2014], Feldman és szerzőtársai [2005], Brown [2011]). További kutatások azt is alátámasztják, hogy az ilyen tulajdonságokkal jellemezhető szereplők általában minden iparágban megtalálhatók, így jelenlétük a gazdasági tevékenység típusától független (Mason-Brown [2013]). Magyarországra vonatkozóan Reszegi-Juhász [2016] jut hasonló következtetésekre a vállalatok teljesítményének vizsgálata során.

A gazdasági szereplők koncentrálódását elsőként Marshall [1890] vizsgálta, amikor a gazdasági tevékenységek területi sűrüsödését figyelte meg. Később ez a munka alapozta meg a porteri innovatív klaszterek szakirodalmát. Porter versenyképesség-elméletében megjelenik a regionális koncentráció fontossága, a tevékenységi szakosodás, valamint a klaszterre jellemző heterogén összetétel. Ezen túlmenően a résztvevők stratégiájában egyidejüleg van jelen a verseny és az együttmüködés. A gazdasági szereplők az ilyen regionális klaszterekben való részvétellel az együttmüködéseknek köszönhetően különféle pozitív externáliák előnyeit élvezhetik. Ezek között a pozitív külső gazdasági hatások között megkülönböztethetünk urbanizációs és lokalizációs előnyöket, amelyeket az ilyen rendszereken belül működő szereplők kiaknázhatnak.

Az urbanizációs előnyök azok a pozitív külső hatások, amelyeket az egy területen tevékenykedő vállalatok használhatnak ki, míg a lokalizációs előnyök esetében szükség van tevékenységi szakosodásra. Ezek kiaknázása érdekében fontos a földrajzi közelség a vállalatok számára (Porter [1990], [1998], [2003], Szanyi és szerzötársai [2009]).

Az innovatív klaszterekhez képest az általunk vizsgált, vállalkozói ökoszisztémára építő megközelítés több ponton eltér a regionális klaszterek definíciójától. A vállalkozói ökoszisztéma az egyén, a vállalkozó szintjéről építkezik, középpontjában az ambiciózus vállalkozók állnak, akik a schumpeteri típusú értékteremtés alapját adják (Schumpeter [1980/1934], Vogel [2013], Stam [2015]). A vállalkozói ökoszisztémát ez alapján elsőként Moore [1993] definiálta, mint egyének és szervezetek gazdasági közösségét. A szerző üzleti ökoszisztémákról beszélt, amelyekben megjelenik egy vezető, aki innovációs képessége révén gazdasági közösséget tud építeni maga köré. Az ilyen típusú ökoszisztémákban a vállalatok és a müködésükben/eredményeikben érintettek (stakeholders) közötti kapcsolat nem feltétlenül formalizált, sokkal inkább hasonlít közös tanuláshoz, közös gondolkodáshoz (Kuti-Bedő [2016]).

A későbbi definíciókban megjelenik a vállalkozói kapacitásteremtés, az új vállalkozások létrehozása és az értékteremtő vállalkozói tevékenység (Ács és szerzötársai [2014],

\footnotetext{
${ }^{1}$ A vállalkozások minőség szerinti pontosabb definiálása szintén megtalálható Stam [2015]-ben. Fontosnak tartjuk továbbá megjegyezni, hogy a vállalkozói ökoszisztémák szakirodalma általában a magasabb minőségi kvalitásokkal rendelkező vállalatokat a nagy növekedési potenciállal azonosítja.
} 
Vogel [2013], Mason-Brown [2013]). Az általunk is vizsgált rendszereket kutató szakirodalomban legtöbbször arra a kérdésre keresik a választ, hogy milyen tényezők szükségesek ahhoz, hogy ilyen sikeres közösségek jöjjenek létre (Isenberg [2010], [2011], Ács és szerzőtársai [2014], Feld [2012], Vogel [2013]). A siker ebben az értelemben a produktív, ${ }^{2}$ növekedésorientált vállalkozást jelenti, azaz a nagy növekedési lehetöségekkel rendelkező vállalatok és ambiciózus vállalkozók koncentrációját (Mason-Brown [2013], Stam [2015]) - ezzel a mennyiségi vállalkozás helyett a minőségi vállalkozást részesítve előnyben. Magyarország vonatkozásában is megfigyelt tény, hogy minden iparágban vannak sikeres vállalatok, és az együttmüködések regionális határokon túlmutatóak is lehetnek (Szanyi és szerzötársai [2009], Reszegi-Juhász [2016]).

A vállalkozói ökoszisztéma definícióinak szintetizálására Stam [2015] tett kísérletet. Szerinte ezek a rendszerek olyan összeköttetésben lévő szereplők és tényezők halmazai, amelyeknek a koordinálásán keresztül produktív vállalkozás valósul meg. A vállalkozói ökoszisztémák vizsgálata során a továbbiakban ezt a definíciót alkalmazzuk. A vállalkozói ökoszisztémák által generált produktív, növekedésorientált vállalkozás megteremtésének és müködtetésének lehetősége a nagy növekedési képességű vállalatok térbeli koncentrálódásához vezethet, amely által a növekedési lehetöségekben megfigyelhető területi különbségek jelennek meg a gazdaságban. Célunk a produktív vállalatok koncentrálódásának megfigyelése, amely a vállalkozói ökoszisztéma általunk használt definíciója alapján azok létezését bizonyíthatja.

\section{Elméleti háttér}

A vállalati növekedési lehetöségek mérésének empirikus alapjait Gilchrist-Himmelberg [1995] fektette le; kutatásaink során, a nemzetközi vizsgálati módszerekhez alkalmazkodva, mi is e módszertant alkalmazzuk. Az $i$-edik vállalat menedzsmentjének célja, hogy a jövőben várható vállalati profitáramok nettó jelenértékét maximalizálja, amit az (1) összefüggéssel írhatunk le: ${ }^{3}$

$V\left(K_{i, t-1}, \theta_{i, t}\right)=\max _{I_{t}} E\left\{\sum_{\tau=t}^{\infty} \beta^{\tau}\left[\pi\left(K_{i, \tau}, \theta_{i, \tau}\right)\right]-c\left(I_{i, \tau}, K_{i, \tau}, \xi_{i, \tau}\right)-I_{i, \tau} \mid \Omega_{i, \tau}\right\}$,

ahol $V$ a vállalat jövőben várható nettó profitárama, $K$ a tőkeállomány, $I$ a beruházás nagysága, $\pi$ a profit-, míg $c$ a költségfüggvény, $\beta^{\tau}$ a diszkonttényező, $\theta$ és $\xi$ exogén sokkok, $E$ a várhatóérték-operátor, $\Omega$ az eseménytér, $i$ az $i$-edik vállalat indexe, $t$ és $\tau$ pedig időindexek.

A profitmaximum elsőrendü feltétele a szélsőérték-probléma szokásos megoldása után a következőképp adódik:

$E\left[q_{i, t} \mid \Omega_{i, t}\right]=1+\frac{\partial c\left(I_{i, t}, K_{i, t}\right)}{\partial I_{i, t}}$,

${ }^{2}$ Jelen tanulmányban produktív vállalkozásokon azokat a vállalatokat értjük, amelyek tőkefelhasználása a standard kritériumoknak megfeleltetve hatékonynak tekinthető.

${ }^{3}$ Az elméleti modell felépítéséhez a szakirodalmat követve támaszkodunk Gilchrist-Himmelberg [1995]-re, valamint felhasználjuk Hayashi [1982] eredményeit. 
ahol

$q_{i, t}=\sum_{s=0}^{\infty} \beta^{s}(1-\delta)^{s}\left[\frac{\partial \pi\left(K_{i, t+s}, \theta_{i, t+s}\right)}{\partial K_{i, t+s}}-\frac{\partial c\left(K_{i, t+s}, \xi_{i, t+s}\right)}{\partial K_{i, t+s}}\right]$,

ahol $\delta$ az amortizáció mértéke. ${ }^{4} \mathrm{~A}$ (2) és (3) összefüggések együttese azt mutatja, hogy a várható maximális profitot biztosító beruházási szint esetén a tőke anticipált határprofitjának meg kell egyeznie a határköltségével. Jelölje $y_{i, t}$ a vállalat egységnyi tőkére jutó beruházási nagyságát, vagyis:

$y_{i, t}=\frac{I_{i, t}}{K_{i, t}}$.

Ekkor a (2) és (3) egyenletek átrendezésével, valamint alkalmazva a (4) jelölést, a következő összefüggéshez juthatunk:

$y_{i, t}=\frac{1}{\alpha} E\left[q_{i, t+s} \mid \Omega_{i, t}\right]+\gamma_{i}+\xi_{i, t}$,

ahol látható, ${ }^{5}$ hogy az egységnyi tőkére jutó beruházások nagysága függ a várható határprofit diszkontált nagyságától. Amennyiben a menedzserek profitvárakozásairól feltételezzük, hogy statikus jellegüek, akkor a várható határprofit meghatározó tényezői származtathatók a vállalat pénzügyi mutatóiból (például egységnyi tőkére jutó nettó árbevétel), amely mutatókat, mint a határprofit meghatározóinak mátrixát, jelöljük $Z$-vel. Ekkor a $Z$ mátrix által tartalmazott oszlopvektorok közül a megfelelő változó értelmezhető a marginális $Q$ érték közelítő változójaként (proxy), amely a fundamentális $Q$ mutató egyik reprezentációja. Ebben az esetben a (6) formájú általános regressziós modell felírására van lehetőségünk:

$y_{i, t}=\mu_{i}+\beta Z_{i, t}+\xi_{i, t}$

amely egyenletben az egységnyi tőkére jutó beruházás, valamint a várható határprofit közötti összefüggésből adódóan a megfelelő $\beta$ paraméter értelmezhető az $1 / \alpha$ mutatóként, amelyet kiigazítási sebességnek nevezhetünk. A kiigazítási sebesség megmutatja, hogy a vállalat milyen mértékben reagál a növekedési lehetőségekre. A $Z$ mátrixban szereplö egységnyi tőkére jutó nettó árbevétel - mint a fundamentális $Q$ érték statikus várakozások mellett értelmezett reprezentációja - a vállalati növekedési lehetőségek közelítő változójaként értelmezhető.

Az alapmodellben a beruházási döntések attól függnek, hogy a vállalat milyen hatékonyan tudja felhasználni a befektetett tőkéjét. ${ }^{6} \mathrm{Ha}$ az egységnyi tökére jutó nettó árbevétel értéke 1 felett van, a menedzserek hatékonyan tudják felhasználni a vállalat tőkéjét, és beruházási döntéseiket arra alapozzák, hogy a jövőben is képesek

\footnotetext{
${ }^{4}$ A tőkeállomány-nagyság a tőkeakkumulációs egyenletre vezethető vissza. Részletesebb leírásért lásd Gilchrist-Himmelberg [1995].

${ }^{5}$ Az egyenletben szereplő $\alpha$ paraméter és $\gamma$ tag az általánosan használt kiigazitásiköltség-függvények elemei (bővebben lásd Gilchrist-Himmelberg [1995]).

${ }^{6} \mathrm{~A}$ tőkehatékonyság a modell szerint a menedzserek profitvárakozásait is meghatározza.
} 
lesznek fenntartani a jelenben megfigyelt hatékonyságot. Ez a fajta várakozás jól illeszkedik a kutatók által megfigyelt túlzott menedzseri optimizmus jelenségéhez (Ben Mohamed és szerzőtársai [2013]).

Az első empirikus kutatások során a modellek magyarázó ereje alacsony volt, így az alapmodellt később oly módon terjesztették ki, hogy a beruházási döntéseket a növekedési lehetőségeken felül a vállalat pénzügyi helyzete is befolyásolja (Gilchrist-Himmelberg [1995], Erickson-Whited [2000]). Az optimális beruházási döntések feltétele, hogy a vállalat számára megfelelö növekedési potenciál legyen elérhetö, és elegendő forrás álljon rendelkezésre az invesztíció megvalósításához (La Rocca-La Rocca [2007]).

Ennek megfelelően mi is a következők szerint bővítjük modellünket:

$y_{i, t}=\mu_{i}+\beta X_{i, t}+\xi_{i, t}$

ahol az $X$ mátrix tartalmazza az előzőkben bemutatott $Z$ mátrixot, valamint a fentebb bevezetett pénzügyi helyzethez kapcsolódó magyarázó változókat.

A beruházási döntések torzulhatnak is (Kuti [2011]): előfordulhat túlzott beruházottság (Jensen [1986], Stulz [1990]), alulberuházottság (Myers [1977]), a kockázat eltolódása (Jensen-Meckling [1976]) és a kockázatkerülés problémája (Brito-John [2002]). Ebben az esetben a vállalat által generált cash flow ingadozás kiemelkedő jelentőségü lehet (Fazzari és szerzőtársai [1988], Kaplan-Zingales [1997]). További kiterjesztés figyelhető meg Ryan és szerzőtársai [2014] munkájában, amelyben megjelenik a pénzügyi szolgáltatók piaci koncentrációja is. A módszerek továbbfejlesztésével szemben Erickson-Whited [2000] fogalmazott meg kritikát, amely szerint a marginális $Q$ közelítő változójaként használt mutatószámok általában nem megfelelően jellemzik a vállalatok növekedési lehetőségeit, ami nagyban befolyásolhatja a finanszírozáshoz kapcsolódó mutatószámok paramétereit és magyarázó erejét. A szerzőpáros a modellek feltételezéseit helytállónak tartja, de a kiterjesztés során bevont magyarázó változókhoz tartozó paraméterek értelmezése a marginális $Q$ közelítő változójának torzítása miatt kifejezetten a részminták esetében nehézkes. A cash flow-hoz tartozó paraméter tekintetében Tirole [2005] is hasonló következtetésre jut.

A vállalkozói ökoszisztéma kiválasztott definíciójához alkalmazkodva a minőségi, produktív vállalkozást a tőkehatékonyság mérésével igyekszünk megfigyelni, amelyet az egységnyi tőkére jutó nettó árbevétel mutatójával közelítünk. Ha a vállalat a befektetett tőkéjét hatékonyan használja, akkor számára elérhetők profitábilis beruházási lehetőségek, azaz jók a növekedési lehetőségei. A definíció alapján a produktív vállalkozás megvalósulása a vállalkozói ökoszisztémák megjelenésének is nagyban köszönhető. Mivel a vállalatok beruházási döntései a tőkehatékonyságtól függnek, a produktív vállalatok menedzserei a beruházások megvalósítása mellett döntenek. Ha egy adott területen müködik vállalkozói ökoszisztéma, akkor ennek köszönhetően az egységnyi tőkére jutó beruházás mértéke nagyobb, $s$ a töke hasznosulása vélhetően produktívabb is. Így az empirikus vizsgálatok során azokat a területeket keressük, ahol a vállalkozás produktivitása nagyobb területi egységek tekintetében - például települési szinten - is kimutatható, és ezáltal az egységnyi tőkére jutó árbevétel és az egységnyi tőkére jutó beruházás általánosan magasabbnak 
tekinthető. Ezenkívül szándékunkban áll vizsgálni, hogy ezek a területek a gazdaságban koncentráltan vannak-e jelen, vagy a produktív vállalkozás inkább sokkal elszigeteltebb módon szórt térszerkezetben valósul meg.

\section{Adatok}

A kiterjesztett alapmodell térökonometriai továbbfejlesztésének empirikus tesztelésére a Területi Információs Rendszer (teir.hu) biztosított hozzáférést a NAV által közölt társasági adóbevallások kiemelt adatainak településszintű aggregátumaihoz. A társasági adóbevallások adatait a 2013-2014-es üzleti évre vonatkozóan gyüjtöttük össze. Az adatállományban a vállalatokat a székhelyük alapján rendelték településekhez, így a társasági adóbevallás adott településhez tartozó sorai az ott székhellyel rendelkező vállalatok társasági adóbevallásai sorainak összegeként adódnak. Hasonló tevékenység szerinti aggregátumokat használ Bélyácz [2015] a vállalati növekedés vizsgálata során, illetve Baloghné-Mundaca [2015] a tőkeszerkezeti döntések vizsgálata során.

A székhely szerinti besorolás felveti azt a problémát, hogy a vállalatoknak más településen is lehetnek telephelyeik, ahol a valós tevékenységük zajlik, teljesítményüket mégis a székhely szerint veszik figyelembe, így az egyes regionális hatások rejtve maradhatnak. Példaként említhetjük, hogy a vállalatokat érintő kedvező helyi adók hatására a vállalatok száma egy-egy településen megnőhet, vagy vállalatok pályázati források lehívása miatt a konvergenciarégiókba helyezhetik a székhelyüket, miközben tevékenységüket más régiókban folytatják.

Magyarországon 2016-ban 3155 települést tartott nyilván a Központi Statisztikai Hivatal; a települések 86 százalékára vonatkozóan állnak rendelkezésünkre adatok, mivel a TEIR adatbázisa szerint a vizsgált időszakban 2709 településre volt bejegyezve vállalkozás. A településszerkezet változása két esetben befolyásolta a megfigyelések számát, aminek hatását az adatgyüjtés során elimináltuk. Az adatállományról így elmondható, hogy aggregált formában az összes társaságiadó-bevallást készítő vállalat adata rendelkezésünkre állt adott településre vonatkozóan.

A modellünkben használt mutatószámokat a társaságiadó-bevallásban szereplő mérleg- és eredménykimutatás megfelelő soraiból származtattuk. A mutatók esetében a hányadosképzés miatt keletkező extrém értékek kezelése érdekében az eloszlások 97,5. percentilisét figyelembe véve az adatokat vinzorizáltuk (az extrém értékeket az eloszlás adott percentiliséhez tartozó értékkel helyettesítettük, winsorization).

$\mathrm{Az}$ 1. ábrán a vállalatok számának településszintű kvartiliseit ábrázoló térképet láthatunk. A térképen jól látszik, hogy a vállalkozások száma a nagyobb városokban, megyeszékhelyeken sürüsödik, illetve hogy a közép-magyarországi régióban, az Észak-Dunántúlon és az Alföldön nagyobb a vállalkozói aktivitás, mint a többi régióban. A térkép alapján következtethetünk arra, hogy az urbanizációs külső hatások hogyan vonzzák a vállalatokat a nagyobb városokba. A vállalatok tekintetében a nagyobb piacok, a potenciális együttmüködő partnerek elérhetősége, a nagy, speciális igényeket kielégítő munkaerőpiac, a tevékenységhez szükséges szolgáltatások megléte, mind olyan előnyök, amelyeket az egymáshoz közel tevékenykedő vállalatok 
ki tudnak használni (Szanyi és szerzőtársai [2009]). Reszegi-Juhász [2016] is kiemeli, hogy a bérszínvonal, a munkaerő kínálata, a társadalmi és környezeti tényezők, a felsőoktatás színvonala és különböző iparági tradíciók is befolyásolhatják a vállalat letelepedési döntéseit. Ezzel magyarázható, hogy a nagyobb városok környékén valószínűsíthetően nagyobb a vállalkozói aktivitás is, így megnő a vállalatok mennyisége.

1. ábra

A vállalatok számának településszintű kvartilisei

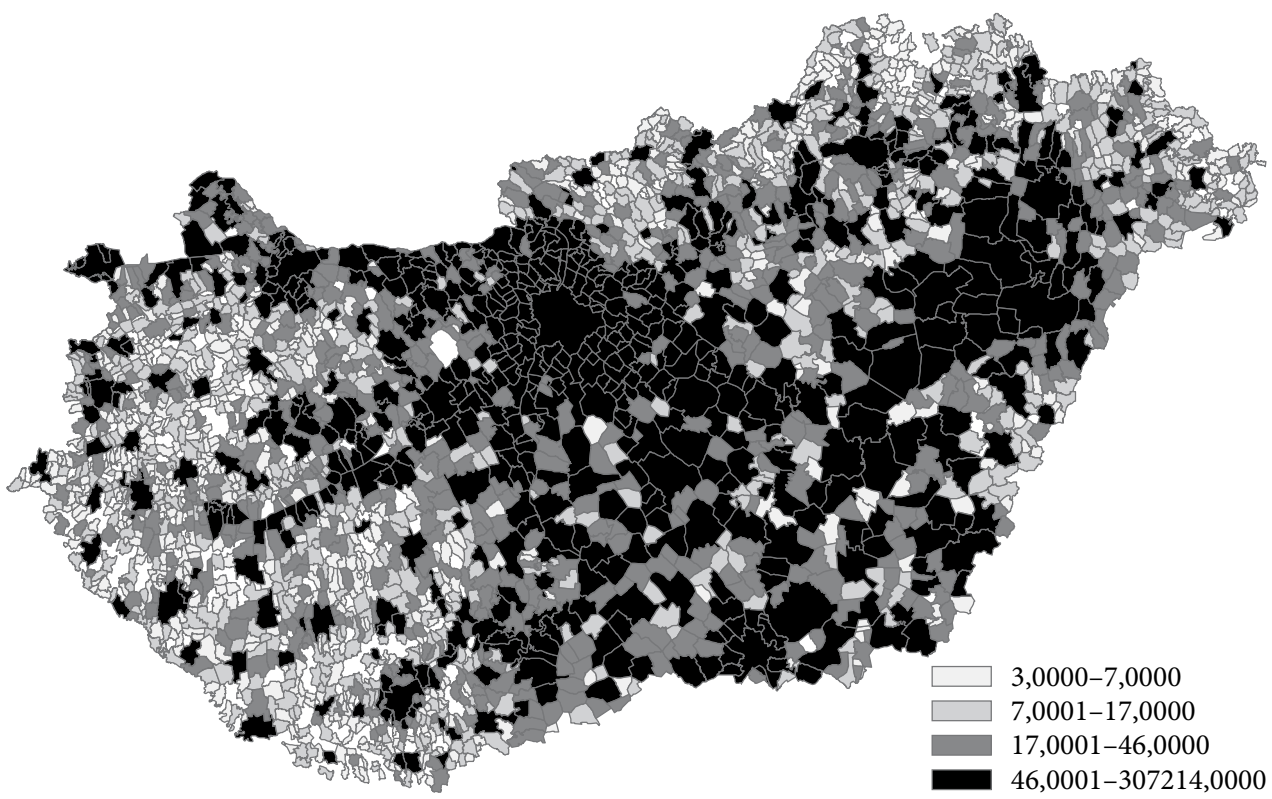

Megjegyzés: az ábrán a színárnyalat erősödése az adott település magasabb osztályközbe tartozását jelzi a vállalatok számának kvartilisei alapján a 2014. évre vonatkozóan.

Forrás: saját szerkesztés.

A 2. ábrán az értékesítés nettó árbevételének egységnyi tőkére jutó értékét ${ }^{7}$ láthatjuk kvartilisek szerinti települési szintü bontásban. Ez a mutató azt jelzi, hogy a vállalatok az adott településen milyen hatékonyan használják fel tőkéjüket. Az általunk épített modellben ezt a változót a növekedési lehetőségek közelítő változójaként alkalmazzuk. A mutató értékéből következtethetünk arra, hogy az adott településen a vállalkozói aktivitás produktív módon valósul-e meg, így konklúziókat vonhatunk le a tekintetben, hogy a vállalkozások minőségét mi jellemzi az adott településen. A vállalkozói ökoszisztémák definíciójából fakadóan a mutató magas értéke sejthetően valamilyen gazdasági közösség tevékenységének eredményéből következik.

A jobb értelmezés érdekében tekintsük az aggregátumnak a mutatószám mögött meghúzódó vállalati szintű eloszlását! Ahol az aggregált mutatószám értéke magas, ott a mögöttes eloszlásban meghatározók a magas tőkehatékonyság mellett müködő

\footnotetext{
${ }^{7}$ A mérlegföösszeghez viszonyított értékét.
} 
2. ábra

Az egységnyi tőkére jutó árbevétel településszintü kvartilisei

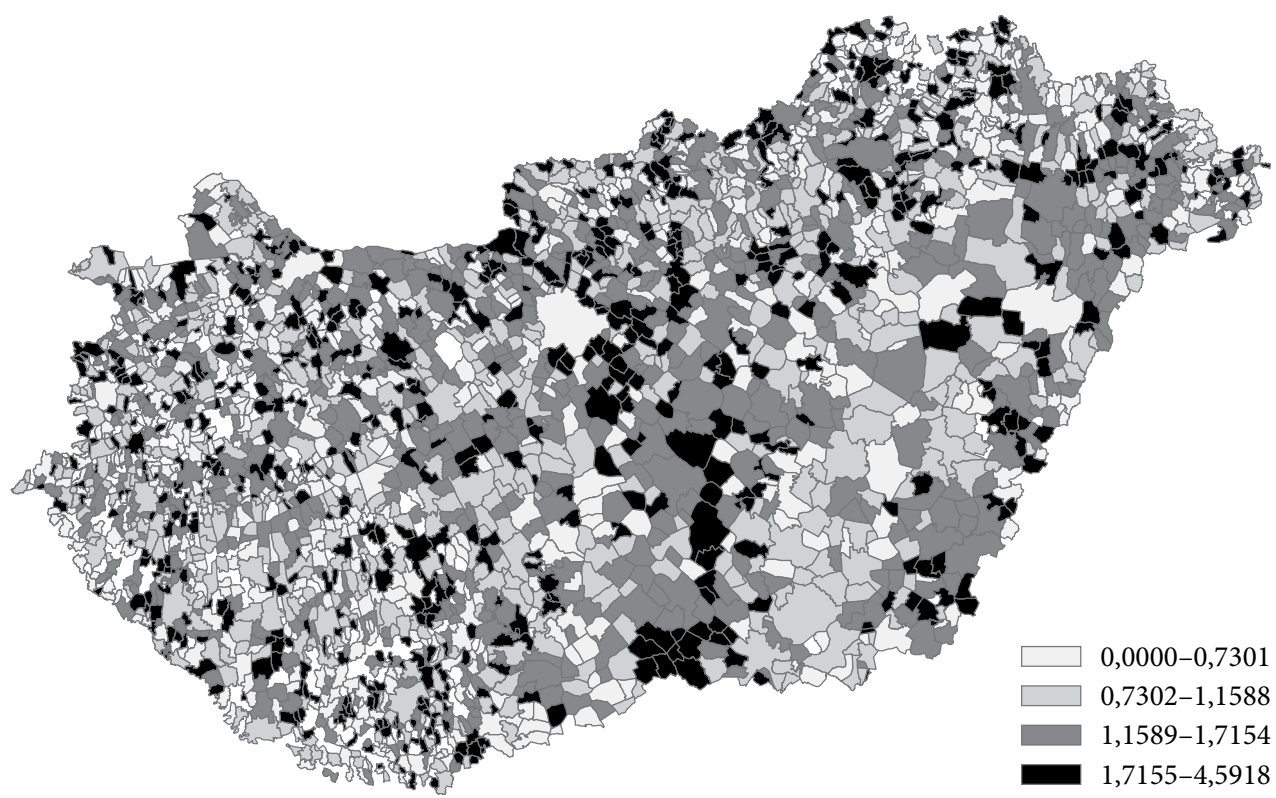

Megjegyzés: az ábrán a színárnyalat erősödése az adott település magasabb osztályközbe tartozását jelzi az egységnyi tőkére jutó árbevétel mutató kvartilisei alapján a 2014. évre vonatkozóan. Forrás: saját szerkesztés.

vállalatok, míg az alacsony érték adódhat abból, hogy túlsúlyban vannak az alacsony tőkehatékonysággal müködő vállalatok. A jelzőszámok értékét így befolyásolhatja az is, hogy hiába magas a vállalkozói aktivitás az adott településen, ha a vállalatok töredéke képes csak hatékony tőkefelhasználást elérni. Erre a legszembetűnőbb példa - amely az 1. ábrán is jól látható - Budapest, ahol az elmúlt időszakban a startup élet felvirágzott, a főváros lett a kockázati tőke fellegvára. Az 1. és a 2. ábra összevetéséből jól látható, hogy a fővárosban és Közép-Magyarországon a vállalkozói aktivitás magas, ezzel szemben a vállalkozás hatékonysága alacsony. Az aggregált tökehatékonysági mutató alacsony értékének okára Reszegi-Juhász [2016] hívta fel a figyelmet, amikor arra a következtetésre jutott, hogy Budapest ugyan a vállalkozás fellegvára, a magas tőkehatékonysággal müködő vállalatok aránya azonban nem kiemelkedő. A települési szinten aggregált tőkehatékonysági érték a legtöbb nagyvárosnál és megyeszékhelynél - mint például Győr, Sopron, Pécs, Székesfehérvár - ezt a jelenséget erősíti meg. A vállalkozói ökoszisztémák térbeli megjelenéséről a 2. ábra előzetesen arra enged következtetni, hogy a nagyvárosokban megvalósuló vállalkozói aktivitás pozitív hatással van a közvetlen környezetben lévő települések vállalkozói aktivitásának minőségére.

A 3. ábrán a befektetett eszközök tárgyévi bruttó növekményének egységnyi tőkére jutó értékeit ${ }^{8}$ láthatjuk kvartilisek szerinti települési szintü bontásban; az ábra

\footnotetext{
${ }^{8}$ A mérlegföösszeghez viszonyított értékét.
} 
segítségével az egységnyi tőkére jutó beruházás alakulását figyelhetjük meg. A mutató településszintủ aggregátumának pozitív értéke azt jelzi, hogy az adott település nettó beruházói pozícióban van. Ez azt jelenti, hogy a vállalatok többsége úgy gondolja, hogy érdemes az adott településen tőkét befektetni, ezáltal a település fejlődőképes. A beruházási döntések tekintetében érzékelhető, hogy az egységnyi tőkére jutó beruházás alkalmas méröszáma a vállalkozás minőségének, így megfelelö lehet a vizsgált közösségek létezésének megfigyelésére.

\section{3. ábra}

Az egységnyi tőkére jutó beruházás településszintü kvartilisei

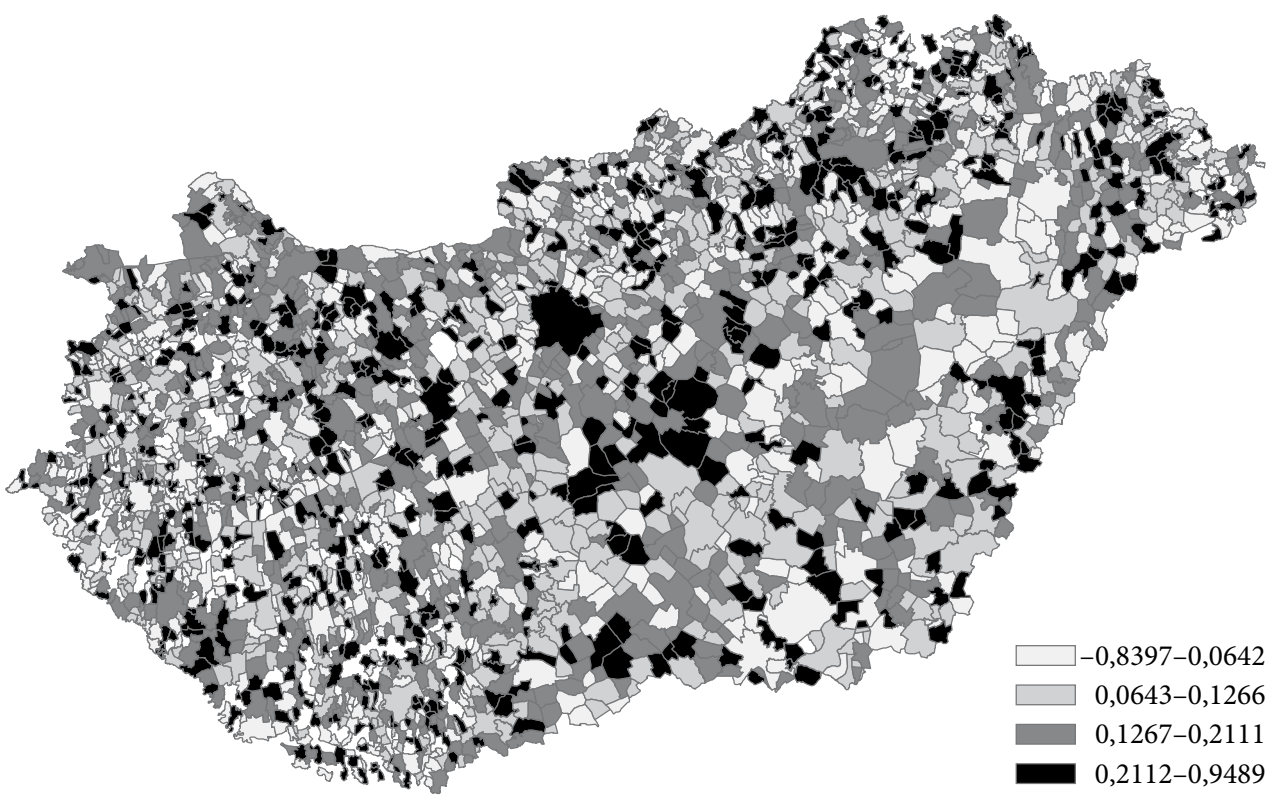

Megjegyzés: az ábrán a színárnyalat erősödése az adott település magasabb osztályközbe tartozását jelzi az egységnyi tőkére jutó beruházás mutató kvartilisei alapján a 2014. évre vonatkozóan.

Forrás: saját szerkesztés.

\section{Modellbecslések és eredményeik}

A települések beruházásokra vonatkozó tulajdonságainak vizsgálatakor a vállalati szintü beruházási döntésekből indultunk ki. A modellek empirikus tesztelése során arra kerestük a választ, hogy milyen tényezők befolyásolják a beruházások nagyságát adott településen. Elözetes feltételezéseink alapján az egységnyi tökére jutó beruházás mutatója megfelelő mérőszáma lehet a vállalkozás minőségének. Az általunk gyüjtött adatok a korábbiakban bemutatott modellel ellentétben egy keresztmetszeti adatállomány vizsgálatát tették lehetővé. Ennek fényében a (6) összefüggés redukálására kényszerültünk, így a következö modell becslését végeztük el: 
$y_{i}=\beta_{0}+\beta_{1} q_{i}+\beta_{2} h l k v_{i}+\beta_{3} j t n_{i}+u_{i}$

ahol $y$ a befektetett eszközök bruttó növekménye, $q$ a tárgyévi nettó árbevétel, $h l k v$ a tárgyévi hosszú lejáratú kötelezettségek változása, míg jtn a tárgyévi jegyzett tőke növekménye. Annak érdekében, hogy a közelítő változóként alkalmazott mutató értelmezhető legyen a fundamentális $q$ mutató reprezentációjaként, minden változót elosztottunk a bázisévi mérlegföösszeggel, ${ }^{9}$ így tulajdonképpen mindegyik változónk az $i$-edik település aggregált mérlegföösszegéhez viszonyított nagyság. ${ }^{10}$

A (8) összefüggésből jól látszik, hogy az elméletben felépített (5) modell alapján végzett becslés során a $\beta_{1}$ paraméter határozza meg az $1 / \alpha$ kiigazítási sebességet, amely megmutatja, hogy átlagosan milyen gyorsan és milyen költségek mellett alkalmazkodnak a vállalatok a növekedési lehetöségekhez. A $\beta_{2}$ és $\beta_{3}$ paraméterek ezzel szemben a pénzügyi helyzethez köthetök. Ezek a paraméterek mutatják meg, hogy a településeken a beruházások nagysága mennyire függ az adott településen bejegyzett vállalatok forrásbevonó képességétől. A hosszú lejáratú kötelezettségek esetén a település vállalatai lehetnek nettó hitelfelvevői vagy nettó hitel-visszafizetői pozícióban, míg a jegyzett tőke esetén a tulajdonosi vagy kockázati tőke elérhetősége játszik szerepet. Igyekeztünk továbbá olyan magyarázó változókat bevonni a vizsgálati körbe, amelyek a települések olyan adottságait veszik figyelembe, amelyek hatással lehetnek a vállalatok beruházási döntéseire.

Ennek érdekében a következő becslést is elvégeztük:

$y_{i}=\beta_{0}+\beta_{1} q_{i}+\beta_{2} h l k v_{i}+\beta_{3} j t n_{i}+\delta_{1} M S Z_{i}+\delta_{2} F I_{i}+\delta_{3} A P_{i}+u_{i}$,

ahol az új kontrollváltozók rendre bináris jellegüek a következő értékekkel: az MSZ értéke 1 , ha az adott település megyeszékhely, egyébként 0 . Az FI változó értéke 1 , ha az adott településen található felsőoktatási intézmény, ${ }^{11}$ egyéb esetben 0 , míg az $A P$ változó értéke 1, ha az adott településen vagy közvetlen közelében autópálya halad át.

Mivel a kétértékủ változók bevezetésével az OLS eljárás alkalmazása nem mindig vezet torzítatlan eredményre, ${ }^{12}$ a becsléseket minden esetben elvégeztük az általánosított momentumok módszerével (GMM) is. ${ }^{13} \mathrm{~A}$ becslések eredményét az 1 . táblázat tartalmazza.

Az eredmények alapján elmondható, hogy a kibővített modell (8) magyarázó változói szignifikánsak, és a paraméterek gazdasági jelentéstartalma - az együtthatók előjelét és viszonylagos nagyságát tekintve is - megfelelö. A növekedési lehetőségek közelítő változójára vonatkozóan elmondhatjuk, hogy a települések nettó beruházói pozíciója függ attól, hogy a vállalatoknak adott településen milyen növekedési

${ }^{9}$ A hányadosokat a modellfelírások során kisbetűkkel jelöltük.

${ }^{10}$ Tóth-Pajor-Farkas [2016]-ban hasonló induló modell becslését végeztük el, azonban az adatállomány teljes különbözősége miatt az eredmények értelmezése is eltér, valamint a jelen tanulmány keretei között végzett modellbővítési eljárások is merőben mások.

${ }^{11}$ A felsőoktatási intézményeknél a teológiai képzést nyújtó intézményeket nem vettük figyelembe.

${ }^{12}$ Hiszen a többi egyenletbeli változó rendre hányados.

${ }^{13}$ Az OLS becslések esetében White-féle robusztus standard hibák segítségével kezeltük a heteroszkedaszticitást. A GMM becslések esetében a paraméterek számával azonos számú momentum feltételt határoztunk meg. 
1. táblázat

A modellbecslések eredményei

\begin{tabular}{|c|c|c|c|c|}
\hline Változó & (8) modell OLS & (8) modell GMM & (9) modell OLS & (9) modell GMM \\
\hline Konstans & $\begin{array}{l}0,0822^{\star * *} \\
(0,0059)\end{array}$ & $\begin{array}{l}0,08468^{\star * *} \\
(0,007)\end{array}$ & $\begin{array}{l}0,0836^{\star * *} \\
(0,0059)\end{array}$ & $\begin{array}{l}0,0853^{\star * *} \\
(0,0071)\end{array}$ \\
\hline$q$ & $\begin{array}{l}0,0492^{\star \star \star} \\
(0,0036)\end{array}$ & $\begin{array}{l}0,046376^{* * *} \\
(0,0052)\end{array}$ & $\begin{array}{l}0,0492^{\star \star \star} \\
(0,0036)\end{array}$ & $\begin{array}{l}0,0462^{\star \star \star} \\
(0,0052)\end{array}$ \\
\hline$h l k v$ & $\begin{array}{l}0,8361^{\star \star \star} \\
(0,036)\end{array}$ & $\begin{array}{l}0,8484^{* * *} \\
(0,0668)\end{array}$ & $\begin{array}{l}0,8364^{\star \star \star *} \\
(0,036)\end{array}$ & $\begin{array}{l}0,8485^{\star * \star} \\
(0,0669)\end{array}$ \\
\hline jtn & $\begin{array}{l}0,9980^{\star * *} \\
(0,069)\end{array}$ & $\begin{array}{l}1,0057^{\star * \star} \\
(0,1434)\end{array}$ & $\begin{array}{l}0,9998^{\star * *} \\
(0,0069)\end{array}$ & $\begin{array}{l}1,0032^{\star * *} \\
(0,1432)\end{array}$ \\
\hline$M S Z$ & & & $\begin{array}{l}-0,0409 \\
(0,0574)\end{array}$ & $\begin{array}{l}-0,0413 \\
(0,0532)\end{array}$ \\
\hline FI & & & $\begin{array}{c}0,0136 \\
(0,0561)\end{array}$ & $\begin{array}{c}0,0151 \\
(0,0426)\end{array}$ \\
\hline$A P$ & & & $\begin{array}{c}-0,0166 \\
(0,0133)\end{array}$ & $\begin{array}{c}-0,0162 \\
(0,012)\end{array}$ \\
\hline$R 2$ & 0,2991 & & 0,2997 & \\
\hline
\end{tabular}

*** 1 százalékos, ${ }^{* *} 5$ százalékos, ${ }^{\star} 10$ százalékos szinten szignifikáns. Forrás: saját szerkesztés.

kilátásaik vannak, milyen hatékonyan használták a tőkéjüket, azaz hogy milyen a vállalkozás minősége. A vállalatok hajlandóbbak befektetni a tőkéjüket adott településen, ha úgy gondolják, hogy ezt produktívabb módon tehetik meg. A paraméter értéke a kiigazítás sebességét mutatja meg számunkra. A hosszú lejáratú kötelezettségek változásához tartozó paraméter alapján látható, hogy minél hitelképesebbek a vállalatok adott településen, annál nagyobb a beruházások mértéke. Hasonlóan a jegyzett tőke növekedése esetében, ha a vállalatok több tőkét tudnak bevonni, akkor a beruházások nagysága növekszik. Ilyen tőkebevonási lehetőségek között említhetjük a tulajdonosi tőkét, a kockázati tőkét vagy egyéb pályázati forrásokat.

A (9) modellbe bevont kétértékü változók esetében elmondható, hogy nincs szignifikáns magyarázó erejük, és a három változó közül csak a felsőoktatási intézményekhez tartozó paraméter gazdasági jelentéstartalma értelmezhető. Eredményeink alapján nem figyelhetünk meg megyeszékhelyhatást. Az egyetem harmadik szerepe és az egyetemközpontú vállalkozói kapacitásteremtés sokszor megjelenik a gazdasági közösségek építőköveként (Kuti-Bedő [2016]). Jelen esetben azonban az eredmények ezt nem erösítik meg. Ennek az lehet az oka, hogy a felsőoktatási intézmények és a gazdaság közötti kapcsolat nem általánosítható minden településre, sokkal inkább egy evolúciós folyamat eredménye, amely minden esetet egyedivé tesz. Ennek alapján úgy gondoljuk, hogy ez a funkció egyes felsőoktatási intézmények esetében kiforrottan jelen van, másokéban azonban még gyerekcipőben jár.

Úgy gondoljuk továbbá, hogy újabb változók bevonásával az illeszkedés javítható, de a modell továbbfejlesztése érdekében ismételt adatgyüjtésre lenne szükség. 
A települések tekintetében a munkaerő kínálata is nagyban befolyásolhatja a vállalatok beruházási döntéseit, e tényezőn keresztül feltételezhetően a felsőoktatási intézmények szerepe is jobban megragadható. További befolyásoló tényező lehet a pénzügyi piacok koncentrációja is (Ryan és szerzőtársai [2014]).

A becslések alapján levonhatjuk a következtetést, hogy az egységnyi tőkére jutó beruházás értéke megfelelő mérőszáma lehet a vállalkozás minőségének, mert a vállalatok beruházási döntései nemcsak a vállalat növekedési lehetőségeitől függnek, hanem a finanszírozási források elérhetőségétől és valószínüsíthetően az adott település gazdasági közösséget építő adottságaitól is. A vállalati beruházási döntéseket befolyásoló települési adottságok feltárására jelen modellek nem tértek ki, így a modellek ez irányú fejlesztése további kutatási irányként jelenhet meg.

\section{A modell térbeli kiterjesztése}

Az előző részekben településszinten foglalkoztunk a minőségi vállalkozás megjelenésével, amit a gazdasági közösségek tevékenységének eredményeként értelmeztünk. A következőkben azzal foglalkozunk, hogy megfigyelhetők-e a települési szint felett is gazdasági közösségek, vagyis vizsgálatunk a továbbiakban arra irányul, hogy kimutathatók-e a szakirodalom által sok esetben taglalt regionális szintü ökoszisztémák. Ha a gazdaságban a nettó beruházói pozícióban lévő települések koncentrációja figyelhető meg, az arra enged következtetni, hogy a vállalatok beruházási döntései adott településen függnek a szomszédos települések vállalatainak beruházási döntéseitől. Ha az azonos tulajdonságokkal rendelkező vállalatok településhatárokon átívelően koncentrálódnak egyes területeken, a produktív tulajdonságok lokalizálásával arra következtethetünk, hogy a nevezett régióban nagyobb kiterjedésü, regionális szintü vállalkozói ökoszisztéma működik. Ennek mérésére és a modell további kiterjesztésére kiváló lehetőségeket ad a térökonometria eszköztára (Varga [2002]).

Sok esetben olyan nem mérhetö tényezőkkel állunk szemben, amelyek döntő jelentőségűek egy adott terület szempontjából, és ezért nagyban hozzájárulnak a vállalkozói ökoszisztémák kialakulásához is. ${ }^{14} \mathrm{Az}$ ilyen nem megfigyelhető változók vezethetnek a változók térbeli heterogenitásához, ami nem más, mint a térbeli koncentráció adatokon látható megjelenése. Ennek vizsgálati lehetőségét kínálják a térökonometriai modellek. Közülük a térbeli késleltetés (Spatial Autoregressiv Model, $S A R$ ), valamint a térbeli hiba (Spatial Error Model, SEM) modellje jó lehetőségeket kínál a kihagyott változó - esetünkben a nem mérhetö, ám az ökoszisztéma jelenlétét mérő változó - okozta probléma megoldására (LeSage-Pace [2009]).

Vizsgálatunk során így a nettó beruházói pozícióban levő települések koncentrálódásán keresztül ragadjuk meg a gazdasági közösségek tevékenységének tovagyürüzö hatásait. A kutatáshoz a fenti regressziós modellek eredményváltozójának térben késleltetett értékeit használjuk fel. Ha az adott település vállalatainak beruházási döntései függnek a szomszédos települések vállalatainak beruházási döntéseitől,

\footnotetext{
${ }^{14} \mathrm{E}$ tényezők részletes kifejtése található meg tanulmányunk szakirodalmi bevezetőjében.
} 
akkor megragadhatók a gazdasági közösségek által generált pozitív külső hatások lokális gazdaságra gyakorolt hatásai. Így a munkánk során vizsgált második kérdés a következő: befolyásolják-e az adott településen tevékenykedő gazdasági közösségek a vállalkozás minőségét a szomszédos településeken, így hozva létre regionális szintű vállalkozói ökoszisztémákat?

A térbeli függőség jelenlétét a regressziós modellekben a robusztus Lagrangemultiplikátor- (LM-) tesztek segítségével vizsgálhatjuk (Anselin-Rey [1991]). Különböző térbeli súlymátrixok ${ }^{15}$ segítségével teszteljük modellünket a következők szerint (Anselin-Rey [1991):

1. késleltetett LM-próba,

2. robusztus késleltetett LM-próba,

3. LM-hiba próba,

4. robusztus LM-hiba-próba,

5. SARMA-próba.

Az első két hipotézisvizsgálat a térbeli késleltetés jelenlétét, a harmadik és negyedik a térbeli hiba autokorrelációját, míg az utolsó az úgynevezett térbeli mozgóátlag összefüggését vizsgálja. A nullhipotézisek elutasítása esetén bizonyítékot találunk a térbeli függőség jelenlétére, így esetünkben egyúttal a gazdasági közösségek lokális gazdaságra gyakorolt hatása is kimutatható modellünk segítségével.

A próbák elvégzéséhez a következő típusú súlymátrixokat alkalmaztuk: ${ }^{16}$

- bástya típusú elsőfokú szomszédsági (Rook1),

- bástya típusú másodfokú szomszédsági (RoOK2),

- királynő típusú elsőfokú szomszédsági (QueEN1),

- királynő típusú másodfokú szomszédsági (QUEEN2),

- 5 legközelebbi szomszéd (KNN5),

- 10 legközelebbi szomszéd (KNN10). ${ }^{17}$

A próbákat a (8) és (9) modelleken is elvégeztük, az eredményeket a 2. táblázat tartalmazza.

A térképeken látható mintázatok alapján kialakított intuitív feltételezéseinket a térstatisztikák eredményei nem erősítik meg. Eredményeink szerint sem a (8), sem a (9) modell nem tartalmaz térbeliségnek köszönhető heterogenitást. Így tehát a térbeli késleltetés modellje által implikált tovagyürüző hatás, valamint a térbeli hibamodell

${ }^{15}$ A térbeli súlymátrixok alkalmazásainak és tulajdonságainak kiváló összefoglalóját adja Varga [2002].

${ }^{16}$ A modellek térökonometriai kiterjesztésének egyik kulcsfontosságú pontja a megfelelő térbeli súlymátrix kiválasztása. Sajnálatos módon annak meghatározására, hogy mely típusú mátrix megfelelő egy vizsgálat során, jelenleg még nincsen kifejlesztett ökonometriai módszer, így ez általában a vizsgált probléma alapján dönthető el. Ezért és az eredmények összehasonlíthatósága érdekében több súlymátrix segítségével is elvégeztük a vizsgálatot. A megfelelő súlymátrixok kiválasztásához további segítséget nyújthat Anselin-Rey [1991].

${ }^{17} \mathrm{Az}$ általános formájú területi súlymátrixok két nagyobb csoportra oszthatók, a szomszédsági és a távolságon belüli szomszédsági alapúakra. A kiválasztott mátrixok esetében igyekeztünk figyelemmel lenni az általában használatos szomszédsági fokokra és távolságokra, valamint a különböző típusok vizsgálatára is, ezért esett választásunk a felsorolt hat területi súlymátrixra. 
2. táblázat

Térstatisztikák p-értékei a (8) és a (9) modellben

\begin{tabular}{lcccccc}
\hline Próba & RooK1 & RooK2 & QUEEN1 & QUEEN2 & KNN5 & KNN10 \\
\hline (8) modell & & & & & & \\
Késleltetett LM & 0,3930 & 0,7335 & 0,2961 & 0,7974 & 0,3828 & 0,3198 \\
Robusztus késleltetett LM & 0,8832 & 0,2549 & 0,8269 & 0,1431 & 0,9960 & 0,8645 \\
LM-hiba & 0,3815 & 0,3471 & 0,2927 & 0,3154 & 0,3316 & 0,2255 \\
Robusztus LM-hiba & 0,8100 & 0,1508 & 0,8015 & 0,0789 & 0,6704 & 0,4864 \\
SARMA & 0,6745 & 0,3362 & 0,5613 & 0,2068 & 0,6241 & 0,4728 \\
\hline (9) modell & & & & & & \\
Késleltetett LM & 0,3917 & 0,7585 & 0,2930 & 0,8225 & 0,3962 & 0,3395 \\
Robusztus késleltetett LM & 0,9645 & 0,3037 & 0,9054 & 0,1749 & 0,9928 & 0,8934 \\
LM-hiba & 0,3543 & 0,3965 & 0,2682 & 0,3608 & 0,3416 & 0,2561 \\
Robusztus LM-hiba & 0,7223 & 0,1946 & 0,7144 & 0,1051 & 0,6673 & 0,5294 \\
SARMA & 0,6505 & 0,4113 & 0,5380 & 0,2624 & 0,6361 & 0,5200 \\
\hline
\end{tabular}

Forrás: saját szerkesztés.

által feltételezett, nehezen megragadható régiós sajátosságok generálta hatások sem figyelhetők meg. Ennek oka kereshető abban, hogy az aggregált mutatók az erös vállalkozói aktivitás esetén elrejtik a produktív vállalatokat és az ambiciózus vállalkozókat. Illetve, hogy a települési szint felett a vállalkozás minőségében nincsenek nagy különbségek, nincs térbeli heterogenitás. A magyar gazdaságban nem található olyan kiemelkedő régió, ahol kiemelkedően csak produktív vállalatok lennének jelen.

\section{Következtetések}

A vállalkozói ökoszisztémák vizsgálata során a magyar gazdaságban nem találtunk olyan régiót, ahol a produktív vállalatok koncentráltan lennének jelen, így a térökonometriai modellek is megerösítették Reszegi-Juhász [2016] eredményeit. A régiós hatásokat tekintve, sem a településszintü gazdasági közösségek által generált tovagyürüző, sem pedig a régiós adottságok által implikált hatások nem figyelhetők meg. Ezzel szemben a vállalkozás minőségét mérő mutatók alapján a magyar gazdaságban láthatók kiemelkedő települések, ahol az alkalmazott mutatószámok magas értéke a gazdasági közösségek tevékenységének eredményeként értelmezhető.

A standard regressziós modellek alapján elmondható: a településeken kialakuló gazdasági közösségek tevékenységének eredményalapú méröszáma lehet az egységnyi tőkére jutó beruházások mutatója, mivel mind a település vállalatainak növekedési kilátásai, mind a vállalatok forrásbevonási képessége befolyásolja a településeken a beruházások nagyságát. Ezek alapján a mutató megfelelő indikátora lehet a vállalkozói ökoszisztémák létezésének. 
Ha eltekintünk a vállalkozói ökoszisztéma definíciójából származtatott feltevésünktől, amely párhuzamot von a produktív vállalkozás megvalósulása és a vállalkozói ökoszisztéma létezése között, akkor a szórt térszerkezet kialakulásának magyarázatát kereshetjük a magyar iparfejlődés útfüggőségében is. A dilemma feloldásához a vállalati beruházási döntéseket befolyásoló települési adottságok mélyebb vizsgálata szükséges.

További kutatási irányként a modell kiterjeszthető a települések olyan adottságainak vizsgálatával, amelyek elősegíthetik a gazdasági közösségek kialakulását - ezzel megerősítve a vállalkozói ökoszisztéma megközelítését -, vagy kapcsolódnak az iparfejlesztéshez, ami annak útfüggőségét támasztaná alá.

\section{Hivatkozások}

Ács J. Zoltán-Autio, E.-Szerb LÁszló [2014]: National Systems of Entrepreneurship: Measurement issues and policy implications. Research Policy, Vol. 43. No. 1. 476-494. o. http://dx.doi.org/10.4337/9781784718053.00040.

Anselin, L.-Rey, M. [1991]: New Directions in Spatial Econometrics. Springer-Verlag BerlinHeidelberg, Berlin.

Anyadike-Danes, M.-Bonner, K.-Hart, M.-Mason, C. M. [2009]: Mapping Firm Growth in the UK: The Economic Impact of High Growth Firms. NESTA, London.

Baloghné Balla Andrea-Mundaca Gabriella [2015]: Az exporttevékenység tőkeszerkezeti döntésre gyakorolt hatása: empirikus vizsgálat a magyar feldolgozóipari vállalatok esetében. Megjelent: Bélyácz Iván (szerk.): A vállalati növekedés tapasztalatai az 1993-2012 közötti időszakban. Akadémiai Kiadó, Budapest, 132-181. o.

BÉLYÁcz IvÁN [2015]: Bevezető gondolatok a vállalati növekedés eredményeiről. Megjelent: Bélyácz Iván (szerk.): A vállalati növekedés tapasztalatai az 1993-2012 közötti időszakban. Akadémiai Kiadó, Budapest, 11-49. o.

Ben Mohamed, E.-BACCAR, A.-Bouri, A. [2013]: Investment cash flow sensitivity and managerial optimism: A literature review via the classification scheme technique. Review of Finance and Banking, Vol. 5. No. 1. 7-26. o. http://dx.doi.org/10.2139/ssrn.2240827.

BRITO, J. A.-John, K. [2002]: Leverage and growth opportunities: Risk avoidance induced by risky debt. Working paper University of New York, Salomon Centre, Stern School of Business, http://dx.doi.org/10.2139/ssrn.269580.

Brown, R. [2011]: The determinants of high growth entrepreneurship in the Scottish food and drink cluster. Megjelent: Alsos, G.-Carter, S.-Ljunggren, E.-Welter, F. (szerk.): The handbook of research on entrepreneurship in agriculture and rural development. Edward Elgar, Cheltenham, 8. fejezet. http://dx.doi.org/10.4337/9780857933249.00014.

Brown, R.-LeE, N. [2014]: An Examination of Funding Issues Confronting High Growth SMEs in the UK. Institute for Chartered Accountants in Scotland, Edinburgh.

Du, J.-Gong, Y.-Temouri, Y. [2014]: High Growth Firms and Productivity: Evidence from the United Kingdom. Small Business Economics, Vol. 44. No. 1. 123-143. o. http://dx.doi. org/10.1007/s11187-014-9584-2.

Erickson, T.-Whited, T. M. [2000]: Measurement Error and the Relationship between Investment and q. Journal of Political Economy, Vol. 108. No. 5. 1027-1057. o. http://dx.doi. org/10.2139/ssrn.284428. 
Fazzari, S. M.-Hubbard, G.-Petersen, B. C. [1988]: Financing Constraints and Corporate Investment. Brookings Papers on Economic Activity, 1. 141-195. o. http://dx.doi. org/10.3386/w2387.

FELD, B. [2012]: Startup Communities: Building an Entrepreneurial Ecosystem in Your City. Wiley, New York.

Feldman, M. A.-Francis, J.-Bercovitz, J. [2005]: Creating a Cluster While Building a Firm: Entrepreneurs and the Formation of Industrial Clusters. Regional Studies, Vol. 39. No. 1. 129-141. o. http://dx.doi.org/10.1080/0034340052000320888.

Gilchrist, S.-Himmelberg, C. P. [1995]: Evidence on the Role of Cash Flow for Investment. Journal of Monetary Economics, Vol. 36. No. 3. 541-572. o. http://dx.doi.org/10.1016/03043932(95)01223-0.

Hayashi, F. [1982]: Tobin's Marginal q and Average q: A Neoclassical Interpretation. Econometrica, Vol. 50. No. 1. 213-224. o. http://dx.doi.org/10.2307/1912538.

IsENBERG, D. J. [2010]: How to Start an Entrepreneurial Revolution. Harvard Business Review, Vol. 88. No. 6. 41-50. o.

IsENBERG, D. J. [2011]: Introducing the Entrepreneurship Ecosystem: Four Defining Characteristics. Forbes, május 25. http://www.forbes.com/sites/danisenberg/2011/05/25/introducingthe-entrepreneurship-ecosystem-four-defining-characteristics/\#1e4fa52e38c4.

Jensen, M. C. [1986]: Agency Costs of Free Cash Flow, Corporate Finance, and Takeovers. The American Economic Review, Vol. 76. No. 2. 323-329. o. http://dx.doi.org/10.2139/ssrn.99580.

Jensen, M. C.-Meckling, W. H. [1976]: Theory of the Firm: Managerial Behavior, Agency Costs and Ownership Structure. Journal of Financial Economics, Vol. 3. No. 4. 305-360. o. http://dx.doi.org/10.1002/9780470752135.ch17.

Kaplan, S. N.-Zingales, L. [1977]: Do Investment-Cash Flow Sensitivities Provide Useful Measures of Financing Constraints? The Quarterly Journal of Economics, Vol. 112. 169-216. o. http:// citeseerx.ist.psu.edu/viewdoc/download?doi=10.1.1.196.7531\&rep=rep1\&type=pdf.

Kuti Mónika [2011]: A beruházási és finanszírozási döntések interakciói. Hitelintézeti Szemle, 10. évf. 3. sz. 226-240. o. http://dx.doi.org/10.1162/003355397555163.

Kuti Mónika-Bedő Zsolt [2016]: Az egyetemi vállalkozói ökoszisztémába ágyazott közösségi finanszírozás. Vezetéstudomány, 47. évf. 2. sz. 45-52. o.

La Rocca, M.-La Rocca, T. [2007]: Capital Structure and Corporate Strategy: An Overview. University of Calabria, kézirat, http://dx.doi.org/10.2139/ssrn.1023461.

LeSAGE, J.-PACE, R. K. [2009]: Introduction to Spatial Econometrics. Taylor and Francis Group, London. http://dx.doi.org/10.1201/9781420064254.

Marshall, A. [1890]: Principles of Economics. Macmillan and Co., London. http://dx.doi. org/10.1007/978-1-349-15213-1.

Mason, C. [2009]: Public Policy Support for the Informal Venture Capital Market: A Critical Review. International Journal of Small Business, Vol. 27. No. 5. 536-556. o. http://dx.doi. org/10.1177/0266242609338754.

MAson, C.-Brown, R. [2013]: Entrepreneurial ecosystems and growth oriented entrepreneurship. Background paper prepared for the workshop organised by the OECD LEED Programme and the Dutch Ministry of Economic Affairs on Entrepreneurial Ecosystems and Growth Oriented Entrepreneurship, Hága.

Moore, J. [1993]: Predators and Prey: A New Ecology of Competition. Harvard Business Review, Vol. 71. No. 3. 75-86. o.

MyERs, S. C. [1977]: Determinants of Corporate Borrowing. Journal of Financial Economics, Vol. 5. 147-175. o. http://dx.doi.org/10.1016/0304-405x(77)90015-0. 
Porter, M. E. [1990]: Competitive Advantage of Nations. Simon and Schuster Inc., New York. http://dx.doi.org/10.1007/978-1-349-11336-1.

Porter, M. E. [1998]: Clusters and the New Economics of Competition. Harvard Business School Press, Boston.

Porter, M. E. [2003]: The economic performance of regions. Regional Studies, Vol. 37. No. 6-7. 549-578. o. http://dx.doi.org/10.1080/0034340032000108688.

Reszegi László-Juhász Péter [2016]: A vállalati teljesítmény nyomában. Alinea Kiadó, Budapest.

Ryan, R. M.-O’Toole, C. M.-McCann, F. [2014]: Does bank market power affect SME financing constraints? Journal of Banking and Finance, Vol. 49. 495-505. o. http://dx.doi. org/10.1016/j.jbankfin.2013.12.024.

Schumpeter, J. A. [1980/1934]: A gazdasági fejlődés elmélete. Közgazdasági és Jogi Könyvkiadó, Budapest.

Stam, E. [2015]: Entrepreneurial Ecosystems and Regional Policy: A Sympathetic Critique. European Planning Studies, Vol. 23. No. 9. 1759-1769. o. http://dx.doi.org/10.1080/09654 313.2015.1061484.

Stam, E.-Suddle, K.-Hessels, J.-Van Stel, A. [2009]: High-Growth Entrepreneurs, Public Policies and Economic Growth. Megjelent: Leitao, J.-Baptista, R. (szerk.): Public Policies for Fostering Entrepreneurship: A European Perspective. Springer, New York, 91-110. o. http://dx.doi.org/10.1007/978-1-4419-0249-8_5.

Stam, E.-Hartog, C.-Van Stel, A.-Thurik, R. [2011]: Ambitious Entrepreneurship and Macro Economic Growth. Megjelent: Minniti, M. (szerk.): The Dynamics of Entrepreneurship. Evidence from the Global Entrepreneurship Monitor Data. Oxford University Press, Oxford. http://dx.doi.org/10.1093/acprof:oso/9780199580866.003.0011.

Stam, E.-Bosma, N.-Van Witteloostuijn, A.-De Jong, J.-Bogaert, S.-Edwards, N.Jaspers, F. [2012]: Ambitious Entrepreneurship. A review of the academic literature and new directions for public policy. Adviesraad voor Wetenschap en Technologie-beleid (AWT), Den Haag. https:/www.awti.nl/binaries/awti/documenten/publicaties/2012/1/20/ ambitious-entrepreneurship-summary/ambitious-entrepreneurship-summary.pdf.

STULZ, R. M. [1990]: Managerial discretion and optimal financing policies. Journal of Financial Economics, Vol. 26. No. 1. 3-27. o. http://dx.doi.org/10.1016/0304-405x(90)90011-n.

Szanyi Miklós-Csizmadia Péter-Illéssy Miklós-Iwasaki Ichiro-Makó Csaba [2009]: A gazdasági tevékenység sürüsödési pontjainak (klaszterek) vizsgálata. Statisztikai Szemle, 87. évf. 9. sz. 921-936. o.

Tirole, J. [2005]: The Theory of Corporate Finance. Princeton University Press, Princeton. Tóth-PAJOR Ákos-FARKAS RICHÁRD [2016]: A vállalati növekedési lehetőségek területi különbségeinek modellezése. Megjelent: Lengyel Imre-Nagy Benedek (szerk.): Térségek versenyképessége, intelligens szakosodása és újraiparosodása. JATEPress, Szeged, 353-369. o.

Varga Attila [2002]: Térökonometria. Statisztikai Szemle, 80. évf. 4. sz. 354-370. o.

Vogel, P. [2013]: The Employment Outlook for Youth: Building Entrepreneurial Ecosystems as a Way Forward. An Essay for the G20 Youth Forum 2013, Szentpétervár, 443-449. o. https://papers.ssrn.com/sol3/papers.cfm?abstract_id=2357856.

Wong, K. Y. [2005]: Critical success factors for implementing knowledge management in small and medium enterprises. Industrial Management and Data Systems, Vol. 105. No. 3. 261-279. o. http://dx.doi.org/10.1108/02635570510590101. 